This item was submitted to Loughborough's Research Repository by the author.

Items in Figshare are protected by copyright, with all rights reserved, unless otherwise indicated.

\title{
Living conditions and change in age of menarche in adult Maya mothers and daughters from Yucatan, Mexico
}

PLEASE CITE THE PUBLISHED VERSION

https://doi.org/10.1002/ajhb.23087

\section{PUBLISHER}

(c) Wiley

\section{VERSION}

AM (Accepted Manuscript)

\section{PUBLISHER STATEMENT}

This work is made available according to the conditions of the Creative Commons Attribution-NonCommercialNoDerivatives 4.0 International (CC BY-NC-ND 4.0) licence. Full details of this licence are available at: https://creativecommons.org/licenses/by-nc-nd/4.0/

\section{LICENCE}

CC BY-NC-ND 4.0

\section{REPOSITORY RECORD}

Azcorra, Hugo, Luis Rodriguez, Sudip Datta Banik, Barry Bogin, Federico Dickinson, and Maria Ines Varela Silva. 2019. "Living Conditions and Change in Age of Menarche in Adult Maya Mothers and Daughters from Yucatan, Mexico”. figshare. https://hdl.handle.net/2134/27763. 


\section{Living conditions and intergenerational influences on age of menarche in adult Mayas from Yucatan, Mexico}

\begin{tabular}{|r|l|}
\hline Journal: & American Journal of Human Biology \\
\hline Manuscript ID & AJHB-17-0043.R1 \\
\hline Wiley - Manuscript type: & Original Research Article \\
\hline Complete List of Authors: & $\begin{array}{l}\text { Azcorra, Hugo; Centro de Investigación y de Estudios Avanzados del } \\
\text { Instituto Politecnico Nacional, Departamento de Ecología Humana } \\
\text { Rodriguez, Luis; Universidad Autonoma de Yucatan, Facultad de } \\
\text { Matematicas } \\
\text { Datta Banik, Sudip; Cinvestav-Merida, Department of Human Ecology } \\
\text { Bogin, Barry; Loughborough University, School of Sport, Exercise \& Health } \\
\text { Sciences } \\
\text { DICKINSON, FEDERICO; Centro de Investigación y de Estudios Avanzados, } \\
\text { Departamento de Ecología Humana } \\
\text { Varela-Silva, Maria; Loughborough University, Human Sciences }\end{array}$ \\
\hline Keywords: & $\begin{array}{l}\text { menarche, number of siblings, poverty, Maya women, intergenerational } \\
\text { effects }\end{array}$ \\
\hline
\end{tabular}


Living conditions and intergenerational influences on age of menarche in adult Mayas from Yucatan, Mexico $Q$

Hugo Azcorra ${ }^{1 \S}$, Luis Rodríguez ${ }^{2}$, Sudip Datta Banik ${ }^{1}$, Barry Bogin ${ }^{3}$, Federico Dickinson ${ }^{1}$, Maria Ines Varela-Silva ${ }^{3}$

1: Departamento de Ecología Humana

Centro de Investigación y de Estudios Avanzados del Instituto Politécnico Nacional Mérida, Yucatán, México

Antigua carretera a Progreso Km 6, C.P. 97310

2: Facultad de Matemáticas, Universidad Autónoma de Yucatán, Mérida, Yucatán, México

3: Centre for Global Health and Human Development School of Sport, Exercise and Health Sciences Loughborough University, United Kingdom LE11 3TU $\S$ : corresponding author

hugoazpe@hotmail.com 


\begin{abstract}
Objectives To analyse whether socioeconomic conditions, experienced by mothers and adult daughters during their childhood, are associated with age at menarche (AAM) in daughters.

Methods From September 2011 to January 2014, we collected recalled AAM and childhood living conditions data from a sample of 246 dyads of Maya mothers ( mean age $=59.60$ years) and their adult daughters (mean age $=33.03$ years) from the cities of Merida and Motul in Yucatan, Mexico. Indicators of childhood living conditions were number of siblings, quality of construction materials of the house, and father's absence when these women were pre-menarcheal. One-way ANOVA and multiple regression models were used to assess the association between daughters' childhood conditions and their AAM.
\end{abstract}

Results The recalled mean AAM of adult Maya daughters was 12.05 years (SD = 1.53). After adjusting for the influence of mothers' AAM, number of siblings in both the mothers' and daughters' families directly predicted daughters' AAM (more siblings - later AAM); and a higher index of household conditions of mothers was associated with earlier AAM in daughters. The household conditions index, during the childhood of daughters; and father's absence were not associated with their AAM.

Conclusions Our results suggest that better living conditions experienced by the mothers and daughters during their childhood are associated to lower mean AAM in daughters.

Key words: menarche, number of siblings, poverty, Maya women, intergenerational effects 


\section{INTRODUCTION}

The timing of sexual maturation events during the growth process has significant impacts on reproductive competence and it is a good indicator of ecological conditions (Ellis, 2004). Age at menarche (AAM) is influenced by several factors including genetic predisposition (Anderson, Duffy, Martin, \& Visscher, 2007; Morris, Jones, Schoemaker, Ashworth, \& Swerdlow, 2011; Perry et al. 2009) and a wide range of environmental factors such as nutrition (Berkey, Gardner, Frazier, \& Colditz, 2000; Koprowski, Ross, Mack, Henderson, \& Bernstein, 1999; Moisan, Meyer, \& Gingras, 1990) socioeconomic conditions (Bodzsar \& Zsakai, 2015; Deardorff, Abrams, Ekwaru, \& Rehkopf, 2014; Krzyzanowska, Mascie-Taylor, \& Thalabard, 2015) psychosocial stress (Chisholm, Quinlivan, Petersen, \& Coall, 2005; Ellis \& Garber, 2000; Hermanussen, Lehmann, \& Scheffler, 2012) and endocrine-disrupting chemicals (Buttke, Sircar, \& Martin, 2012; Denham, Schell, Deane, Gallo, Ravenscroft, \& DeCaprio, 2005). There are also some indications that intrauterine conditions have some influence on the timing of maturation (Adair, 2001; Cooper, Kuh, Egger, Wadsworth, \& Barker, 1996; dos Santos Silva, De Stavola, Mann, Kuh, Hardy, \& Wadsworth, 2002; Ibañez, Ferrer, Marcos, Hierro, \& de Zegher, 2000).

From the perspective of human life history theory, current versus future reproduction constitutes a fundamental trade-off during postnatal life and the onset of puberty implies that resources available for the organism (energy and nutrients) switch from growth to reproduction (Hill, 1993). From an evolutionary point of view, Worthman (1999, p. 140) proposed that "humans evolved the capacity to facultatively adjust age at maturity to resolve the adaptive dilemma of variable environmental quality and to determine the optimal course of reproductive development". Recent theoretical contributions have proposed that some phenotypic traits and life history strategies, such as fat deposition are adjusted with exposure to maternal ecologies during development (Kuzawa, 2005; Wells, 2007, 2010): 
Given the high level of ecosensitivity of age of reproductive maturation and the susceptibility shown by individuals to ecological fluctuations faced by ancestors, we may hypothesize that the quality of the environment experienced by women of an older generation can exert some influence on age of menarche of their daughters.

The Maya are the most populous of all Native American ethnicities. There are an estimated 7-8 million Maya living in Guatemala, the Yucatan Peninsula of southern Mexico, Belize, El Salvador, and western Honduras (Bogin et al., 2014; Lovell, 2010). The chronic poverty of the Maya people provides a powerful scenario to test the hypothesis that intergenerational changes in living conditions can help to explain AAM in a sample of adult mothers and their adult daughters. A number of studies focus analysis on intergenerational differences in average menarcheal age according to the changes in living conditions (Cameron \& Nagdee, 1996; Damon, Damon, Reed, \& Valadian, 1969; Ersoy, Balkan, Gunay, \& Egemen, 2005; Malina; Ryan, \& Bonci, 1994), but limited scientific information is available on the influence of living conditions experienced by-previous generations on descendants' AAM. The study of AAM and its determinants is relevant in populations such as the Maya that show important intergenerational change in sociocultural and economic conditions, along with increasing rates of overweight and obesity in children, youth and adults (Azcorra, Varela-Silva, Rodriguez, Bogin, \& Dickinson, 2013; Méndez, Barrera-Pérez, Palma-Solís, Zavala-Castro, Dickinson, Azcorra, \& Prelip, 2016; Varela-Silva, Dickinson, Wilson, Azcorra, Griffiths, \& Bogin, 2012). In the present study, we test hypotheses about the association of socioeconomic conditions experienced by mothers and adult daughters during their childhoods, as well as, father's absence during the daughter's childhood, with $_{2}$ AAM in daughters.

\section{PARTICIPANTS AND METHODS}

This study is part of our research on the influence of socioeconomic and intergenerational factors on the growth and nutritional status of Maya families in a sample of children, their mothers, and their maternal grandmothers from Yucatan, Mexico. In the present study we used data of 246 mother- adult daughter dyads from the cities of Merida $\left(n_{1}=175\right)$ and Motul $\left(n_{2}=75\right)$ in the Yucatan State. 
Merida, the capital city, is located in the north-western part of the state, about 40 kilometers inland from the Gulf of Mexico. In 2015, the population size of Merida was 892,363 inhabitants (INEGI, 2016). The process of rural-to-urban migration initiated in Yucatan several decades ago means that the current population of Merida is composed of about 65,000 Maya people (1) (Lizama Quijano, 2012).

The city of Motul is in the north-central region of the state at approximately $40 \mathrm{~km}$ from Merida city. Until mid- $20^{\text {th }}$ century, Motul was one of the most important production centers of sisal fiber (Agave fourcroydes) in the state. After the fall of the sisal agroindustry, in the 1970s-1980s, Motul began diversifying their economic activities towards livestock, agricultural production of citrus, and more recently, manufacturing operations (maquiladoras) run by foreign capital. In 2015, Motul was inhabited by 36,097 people, $25 \%$ of them being Maya speakers (INEGI, 2016).

\section{Recruitment}

Adult daughters and their mothers were recruited through public primary schools attended by children of the former. In Merida, schools were selected following two criteria: 1) location and concentration of Maya speakers in the city and 2) location and concentration of people with the lowest income. Maya language and lower levels of income characterize Maya people in the city. Mother- adult daughter dyads from Merida were recruited in 47 schools from neighbourhoods located in the south, east and west of the city. In order to allow for greater socioeconomic variability in the sample, we randomly selected 10 participants from each school. Dyads from Motul were recruited in the 12 primary schools of the city. Verbalas well as written informed consent were obtained from the adult daughters and their mothers, Maya ancestry was identified through surnames; the inclusion criterion was the presence of maternal and paternal Maya surnames in both generations. The mean age of the mothers was 59.60 years $(S D=8.64)$, while for daughters the corresponding value was 33.03 years $(S D=5.57)$.

\section{Data collection}

From September 2011 to January 2014 we recorded socioeconomic data from mothers and adult daughters and retrospective information of their AAM. Adult 
women were asked, during interviews to recall the age (nearest year) of their first menstruation. Specifically, interviewers asked, "how old were you when you had your first period". The design and application of questions about AAM followed the methodology used in previous studies in Yucatan by one of the co-authors of this study (FD) during the last three decades (Dickinson, Castillo, Vales, \& Uc, 1995). We applied a socioeconomic questionnaire which included queries on the conditions experienced by the participants (both mothers and adult daughters) during their childhood. Number of siblings and materials of construction of the house, of both mothers and daughters, were used as indicators of living conditions during their childhood. Regarding household conditions, we firstly classified the materials for construction in either perishable (dirt floor, walls of cardboard, metal, or wattle and daub, and metal and palm leaf ceilings), or long-lasting forms (cement floor and cement blocks in walls and ceilings).

Secondly, we constructed a household conditions index defined by three categories in terms of quality: bad (floor, ceiling and walls with perishable materials), good (floor, ceiling and walls with durable materials) and regular (with at least 2 durable materials). Number of siblings was recorded as the total number of offspring in the family as reported by the woman. Quality of housing construction and family size has, previously shown to be sensitive indicators of childhood living conditions in this sample (Azcorra, Dickinson, Bogin, Rodriguez, \& Varela-Silva, 2015). The construction quality of house is directly associated with socioeconomic conditions of the family and provide indirectly an approximation of parents' investment in offspring health and well-being. As reported earlier, the socioeconomic conditions of Mexican families improve as the number of offspring decreases and this indicator is closely related to access and distribution of resources within the household. Several strategies were used to increase the accuracy of childhood living conditions data reported by mothers. Particularly useful was the assistance received by grandmothers from their daughters and other relatives to understand our questions. The questionnaire was designed in such a way that several cross questions confirmed responses already given by the 
participants. Given these strategies, we believe that information on childhood conditions provided by participants was quite reliable.

The value of the household conditions index and number of siblings was tested against the height of participant wor ; in both cases the height of mothers and daughters increased significantly as the conditions of the house improve and the number of siblings decreased. Daughters were also asked about the regular presence of their fathers at home during childhood. We particularly focused on the fathers' absence at home during pre-menarcheal stage ( $<8$ years of age). Several studies have shown that father absence tends to accelerate menarche (Ellis \& Garber, 2000; Ellis, McFadyen-Ketchum, Dodge, Pettit, \& Bates, 1999; Hoier, 2003; Kim, Smith, \& Palermiti, 1997) and several models have been proposed to explain this phenomenon (Belsky, Steinberg, \& Draper, 1991; Hoier, 2003; Kanazawa, 2001).

\section{Ethical concerns}

This research project was approved by the Bioethics Committee for the Study of Human Beings of the Center for Research and Advanced Studies of the National Polytechnic Institute of México and the Loughborough University Ethics Advisory Group. The mothers and daughters signed consent forms to participate in the study. Questions about AAM and anthropometric measurements, were done by women members of our research team.

\section{Statistical analysis}

Student's $t$ and chi-squared tests were used to compare childhood socioeconomic characteristics variables between mothers and daughters. Values of daughters' AAM were compared between categories of houschold conditions index using oneway $A N O V A_{2}$ The association between conditions experienced by mothers and daughters during their childhood and daughters' AAM was analysed through a multiple regression model in which mothers' AAM and numbers of siblings of mothers' and daughters' families were introduced as discrete variables and the household conditions index as two dummy variables with a third (bad household conditions) as the reference. The model was also adjusted for father-absence at 
household introducing this indicator as a dummy variable. Beta weights (standardized coefficients) were calculated to analyze the influence of each predictor in the model. The multiple regression model met the assumptions of residual normality, homogeneity of variance and the variance inflation factor. Statistical analyses were done using the Stata/IC 11.1 for Windows statistical package. Significance level in all analyses was $\alpha=0.05$.

\section{RESULTS}

We found no significant differences in recalled AAM between daughters from Merida and Motul. The mean of recalled AAM for the overall sample of daughters was 12.05 years $(S D=1.53)$ and the corresponding value for mothers was 12.53 years $(S D=1.54)$, the difference being statistically significant $(t=-4.12, P=0.001)$. Socioeconomic conditions experienced by mothers and daughters during their childhood are presented in Table 1. Daughters belonged to families with both lower number of offspring and higher proportions of floors and walls in their houses made of long-lasting materials of construction than mothers. Fable 2 shows the mean values of daughters' $A$ AM according to mother's and daughter's houschold characteristics. There were no-significant differences in daughters' AAM according to their own childhood housing conditions. However, we found a tendency in which daughters' $A$ AM decreased as mothers' housing conditions improved. Even though the overall ANOVA was not statistically significant $(p=0.052)$, the difference in daughters' $A$ AM between the 'bad' and 'good' categories of mother's household conditions was 0.58 years.

\section{PLEASE INSERT TABLE 1 HERE}

\section{PLEASE INSERT TABLEE 2 HEREE}

Results of the model of socioeconomic conditions experienced by mothers and daughters in their childhood to predict daughters' AAM are shown in Table 3. After adjusting for the influence of mothers' AAM, we found that number of siblings in mothers' and daughters' families predicted positively the outcome variable with AAM increasing 0.06-0.11 years for each additional sibling in the family. The 
category of good household conditions of mothers was associated with a lower AAM in their daughters compared to those mothers who reported bad household conditions. Daughter's household conditions index was not significantly associated with their AAM. Father' absence from the household had no significant influence on daughters' AAM. Beta weights (standardized coefficients) showed that mothers' AAM was the most influential predictor followed by the influence of number of siblings in daughters' families, maternal household conditions and number of siblings in mothers' families, respectively.

\section{PLEASE INSERT TABLE 3 HERE}

\section{DISCUSSION}

Limitations of this analysis include the recall of AAM by adult women. However, we consider that our results are little influenced by recall bias. Even though both the daughters and the mothers were, on average, over 30 years old, several prospective studies show that correlation coefficients between documented and recalled AAM range from 0.60 to 0.79 in women older than 30 years of age (Casey et al., 1991; Damon \& Bajema, 1974; Livson \& McNeill, 1962; Must et al., 2002; Zarow \& Chichocka, 2008).

\section{Age at menarche}

The statistically strongest predictor of the daughters' AAM in this study is their mother's AAM. This is a well-known relationship that may be due to genetic, epigenetic, and socio-cultural factors (Ellison \& Reiches, 2012; Worthman, 1999). The AAM recalled by Maya daughters in this study (mean value $=12.05$ years, SD $=1.53$ ) is slightly higher in comparison with the value reported by Datta Banik and collaborators (2015) in a sample of Maya and non-Maya adolescent girls belonging to a wider range of socioeconomic groups from Merida, Mexico ( mean $=11.83$ years, $S D=1.19$ ). The AAM reported in the present analysis is lower than that for urban Maya women from Merida (mean $=12.38, S D=1.19$ ) reported in 1993 (Wolanski, Dickinson, \& Siniarska, 1993) and from several rural Maya communities from Yucatan (ranging 13.0-13.3 years) studied from 1980 to 2000 by Beyene (1989), Daltabuit (1992) and Beyene and Martin (2001). The mean AAM of 
daughters reported in this study is substantially lower than mean values reported for other rural indigenous groups (ranging from 14.6 to 15.3 years) in Mexico (Chavez \& Martinez, 1973; Peña Gómez, 1970; Malina, Peña Reyes, Tan, \& Little, 2004). The mean intergenerational difference on AAM was about 0.50 years and $70 \%$ of daughters recalled an equal or lower AAM than their mothers; these results agree with the suggestion of an intergenerational decline in the mean AAM in urban and rural Maya populations (Siniarska \& Wolanski, 1999).

\section{Childhood living conditions}

Our data suggest that Maya daughters experienced slightly better living conditions in childhood than their mothers-and that these differences are in agreement with modest improvements in living standards observed among the Maya population in Yucatan, during the last decades (Ramirez Carrillo, 2015). Even when the number of offspring reported by daughters is relatively large (Mean $=5.4, \mathrm{SD}=2.7$ ), the intergenerational difference in this indicator was near to 1.4 offspring less than their mothers. Reductions in family size may be related with the demographic policy implemented by the Mexican government at the national level since the early 1970 's, which promoted reproductive health strategies in women from urban and rural regions (Juarez, Quilodran, \& Zavala de Cosio, 1996).

Compared with their mothers, the daughters reported living as children in houses with higher proportions of long-lasting materials of construction for floors and walls. The absence of intergenerational differences in the quality of ceilings might be explained by the higher cost of roof materials compared with floor and wall materials. Recent actions by government-sponsored social programs have supported families living under disadvantaged socioeconomic conditions with the construction of concrete floors and of rooms, used for multiple activities such as sleeping, cooking and eating (Levy, 2006).

\section{Intergenerational living conditions influences on age at menarche}

Overall, the families of the daughters' generation had fewer siblings. This is important because daughters' AAM was more associated with number of siblings than with household construction conditions. Evidence strengthening this 
relationship comes from daughters who reported having more siblings than their mothers. These women reported a mean AAM of 12.20 years $(S D=1.55)$ while those daughters with fewer siblings than their mothers showed a mean of 11.85 years $(S D=1.43)$. In this sense, our results are similar to earlier reports showing a positive association between the number of siblings, total family size, and AAM in daughters (Cameron \& Nagdee, 1996; Malina, Katzmarzyk, Bonci, Ryan, \& Wellens, 1997; Morris, Jones, Schoemaker, Ashworth, \& Swerdlow, 2010; Rigon et al., 2010; Szwed, John, Czapla, \& Kosinska, 2013). The evidence from all these studies supports the hypothesis that number of siblings, and total family size, are correlates of the quality of the socieeconomic environment experienced by girls.

Daughters' AAM was only associated with mothers' household conditions index and not with the daughter's own household conditions index. One reason for this may be mathematical and statistical, that is, the lack of sufficient variation in the daughters' generation. The majority (83\%) of daughters' houses fell into the categories of 'regular' or 'good' quality compared to only $48 \%$ for the mothers' houses.

The variable 'father's absence' was not a significant predictor of AAM. The mean AAM of daughters with absent fathers in the household was 11.96 years (SD = 1.79) while the value for daughters living with their fathers during childhood was 12.06 years $(S D=1.51)$. This finding does not support the hypothesis proposed by some theorists that father's absence leads to an earlier age of sexual maturation. Our finding must be tempered by the fact that only $9 \%(n=23)$ of adult daughters reported father-absence during their childhood.

To the best of our knowledge, the number of studies on intergenerational influences on AAM is limited (Campbell \& Udry, 1995; Chang \& Chen, 2008; Chasiotis, Scheffer, Restemeier, \& Keller, 1998; Gomula-\& Koziel, 2015). A number of studies that approach to a certain extent the influence of living conditions experienced by parents on -ffspring' maturation, have found that higher levels of maternal and paternal education and qualified fathers' occupations, used as indicators of socioeconomic conditions, are associated with earlier AAM in their 
daughters-(Adair, 2001; Cameron \& Nagde, 1996; Campbell \& Udry, 1995; dos Santos Silva, De Stavola, Mann, Kuh, Hardy, \& Wadsworth, 2002). In their study with Taiwanese girls, their mothers, and maternal grandmothers, Chang and Chen (2008) found that maternal place of residence reinforced the influence of maternal AAM On daughters' $A$ AM and that grandmothers' ethnicity reinforced the influence of grandmaternal AAM on granddaughters' AAM. The authors interpret their results to be due to the influence of the interaction between socioeconomic and genetic factors associated with ethnicity on maturation. Chasiotis and collaborators (1998) found in a study of mother-daughter dyads from West $(n=35)$ and East $(n=33)$ Germany that after the reunification in 1989/1990, East German girls changed more in AAM (before $=13.8$ years, after $=13.1$ years) compared with the West German girls (before $=13.1$ years, after $=12.6$ years). This seemed to be due to the more drastic changes in socioeconomic conditions between generations for the East Germans. In a similar way, the present study found that the intergenerational difference in AAM of Maya women was greater when daughters experienced better conditions than their mothers during childhood ( -0.61 years) in comparison to those cases when both generations experienced adverse conditions ( -0.30 years).

A complex set of interactions are associated with the control of $A$ AM. Reviews by Ellison and Reiches (2012), Yermachenko and Dvornyk (2014), and Dvornyk and Haq (2012) found influences of neuroendocrine factors, genomics, epigenetic modifications, nutritional status, and psychosocial stress. A population based study in the United Kingdom found that AAM was statistically significantly influenced by birthweight, ethnicity, weight, height, and exercise at 7 years of age, sib-ship-size, birth-order, and maternal age (Morris, Jones, Schoemaker, Ashworth, \& Swerdlow, 2010). It is also recognized that rapid weight gain in infancy and childhood is associated with an earlier AAM (Adair, 2001; Buckler, 1990; dos Santos Silva, De Stavola, Mann, Kuh, Hardy, \& Wadsworth, 2002).

Pur results are consistent with many studies reporting lower $A$ AM in populations living under better socioeconomic conditions (Attallah, Matta, \& El Mankoushi, 1983; Bielicki, Waliszko, Hulanicka, \& Kotlarz, 1986; Bodzsar \& Zsakai, 2015; 
Bosch, Willekens, Baqui, van Ginneken, \& Hutter, 2008; Deardorff, Abrams, Ekwaru, \& Rehkof, 2014; Henneberg \& Louw, 1995; Khan, Schroeder, Martorell, Haas, \& Rivera, 1996; Krzyzanowska, Mascie-Taylor, \& Thalabard, 2015; Loukid, Baali, \& Hilali, 1996; Padez, 2003; Uche \& Okorafor, 1979).

Based on Mexican public health programs, we may infer that policies to improve reproductive health and to broaden women's choices in terms of family planning will lead, indirectly, to a decrease in the mean AAM. This is supported by governmental policies to reduce family size and our results showing that adult daughters with lower number of siblings had an earlier AAM. The mechanisms that could explain this association are not clear. In theory, strategies related to allocation of energy and nutrients during development can be transmitted from one generation to another (Kuzawa, 2005; Wells, 2007, 2010). It is possible that women with fewer siblings experienced better, conditions during their childhood, including a positive nutritional balance and a lesser burden of disease and stress during their development. This, in turn, may have lead to earlier AAM in the daughters of these women. No, study has addressed the relationship between nutritional status during infancy or childhood and age at maturation in the next generatio However, some studies have found a negative association between maternal BMI and lower values of AAM in daughters (Keim, Braun, Klebanoff, \& Zemel, 2009; Deardorff et al., 2013). The authors of these studies suggest that intrauterine exposition to factors of maternal nutritional balance (e.g. leptin, insulin) could potentially alter the timing of offspring's maturation.

In summary, our results show that relatively better living conditions experienced by mothers and daughters during their childhood is associated with lower values of AAM in daughters.

\section{ACKNOWLEDGEMENTS}

The authors thank those who assisted with the field work, especially Graciela Valentín Sánchez and Adriana Vázquez-Vázquez for taking anthropometric measurements, applying questionnaires and organizing the field work. Additional fieldwork assistance was provided by Paulina Cauich, Frida Gutiérrez and 
Samantha Sánchez. We very much appreciate the mothers and daughters who accepted to participate in the study.

\section{AUTHOR CONTRIBUTIONS \\ HA formulated the initial research question and wrote the first draft of the manuscript. HA and LR analyzed the data. BB, FD, SDB and IVS contributed to the creative process of this paper by providing scientific content and intellectual additions on the subsequent drafts of the manuscript.}

We declare no conflict of interest.

\section{LITERATURE CITED}

Adair, L. S. (2001). Size at birth predicts age at menarche. Pediatrics, 107(4), 1-7. Anderson, C. A., Duffy, D. L., Martin, N. G., \& Visscher, P. M. (2007). Estimation of variance components for age at menarche in twin families. Behavior Genetics, $37(5), 668-677$.

Attallah, N. L., Matta, W. M., \& El-Mankoushi, M. (1983). Age at menarche of schoolgirls in Khartoum. Annals of Human Biology, 10(2), 185-188.

Azcorra, H., Varela-Silva, M. I., Rodríguez, L., Bogin, B., \& Dickinson, F. (2013). Nutritional status of Maya children, their mothers, and their grandmothers residing in the city of Merida, Mexico: revisiting the leg-length hypothesis. American Journal of Human Biology, 25(5), 659-665.

Azcorra, H., Dickinson, F., Bogin, B., Rodríguez, L., \& Varela-Silva, M. I. (2015). Intergenerational influences on the growth of Maya Children: the effect of living conditions experienced by mothers and maternal grandmothers during their childhood. American Journal of Human Biology, 27(4), 494-500. 
Belsky, J., Steinberg, L., \& Draper, P. (1991). Childhood experience, interpersonal development, and reproductive strategy: An evolutionary theory of socialization. Child Development, 62(4), 647-670.

Berkey, C. S., Gardner, J. D., Frazier, A. L., \& Colditz, G. A. (2000). Relation of childhood diet and body size to menarche and adolescent growth in girls. American Journal of Epidemiology, 152(5), 446-452.

Beyene, Y. (1989). From menarche to menopause: Reproductive lives of peasant women in two cultures. Albany: State University of New York Press.

Beyene, Y., \& Martin, M. C. (2001). Menopausal experiences and bone density of Maya women in Yucatan, Mexico. Annals of Human Biology, 13(4), 505-511.

Bielicki, T., Waliszko, A., Hulanicka, B., \& Kotlarz, K. (1986). Social-class gradients in menarcheal age in Poland. Annals of Human Biology, 13(1), 1-11.

Bodzsar, E. B., \& Zsakai A. (2015). Sexual maturation pattern in the mirror of socioeconomic background. Anthropologischer Anzeiger, 72(1), 1-12.

Bogin, B., Azcorra, H., Wilson, H., Vázquez-Vázquez, A., Ávila, M. L., CastilloBurguete, M. T., Varela-Silva, I., \& Dickinson, F. (2014). Globalization and children's diets: the case of Maya of Mexico and Central America. Anthropological Review, 77(1), 11-32.

Bosch, L. M., Willekens, F. J., Baqui, A. H., van Ginneken, J. K. S., \& Hutter, I. (2008). Association between age at menarche and early-life nutritional status in rural Bangladesh. Journal of Biosocial Science, 40(2), 223-237.

Buckler, J. (1990). A longitudinal study of adolescent growth. London: SpringerVerlag.

Buttke, D. E., Sircar, K., \& Martin, C. (2012). Exposure to endocrine-disrupting chemicals and age of menarche in adolescent girls in NHANES (2003-2008). Environmental Health Perspective, 120(11), 1613-1618. 
Cameron, N., \& Nagdee, I. (1996). Menarcheal age in two generations of South African Indians. Annals of Human Biology, 23(2), 113-119.

Campbell, B. C., \& Udry, J. R. (1995). Stress and age at menarche of mothers and daughters. Journal of Biosocial Science, 27(2), 127-134.

Casey, V. A., Dwyer, J. T., Coleman, K. A., Krall, E. A., Gardner, J., \& Valadian, I. (1991). Accuracy of recall by middle-aged participants in a longitudinal study of their body size and indices of maturation earlier in life. Annals of Human Biology, 18(2), 155-166.

Chang, S., \& Chen, K. (2008). Age at menarche of three-generation families in Taiwan. Annals of Human Biology, 35(4), 394-405.

Chasiotis, A., Scheffer, D., Restemeier, R., \& Keller, H. (1998). Intergenerational context discontinuity affects the onset of puberty. A comparison of parent-child dyads in West and East Germany. Human Nature, 9(3), 321-339.

Chavez, A., \& Martinez, C. (1973). Nutrition and development of infants from poor rural areas. III. Maternal nutrition and its consequence of fertility. Nutrition Reports International, 7(1), 1-8.

Chisholm, J. S., Quinlivan, J. A., Petersen, R. W., \& Coall, D. A. (2005). Early stress predicts age at menarche and first birth, adult attachment, and expected lifespan. Human Nature, 16(3), 233-265.

Cooper, C., Kuh, D., Egger, P., Wadsworth, M., \& Baker, D. (1996). Childhood growth and age at menarche. British Journal of Obstetrics and Gynaecology, 103(8), 814-817.

Daltabuit, M. (1992). Mujeres mayas: trabajo, nutrición y fecundidad. México: Universidad Nacional Autónoma de México, Instituto de Investigaciones Antropológicas. 
Damon, A., Damon, S. T., Reed, R. B., \& Valadian, I. (1969). Age at menarche of mothers and daughters, with a note on accuracy of recall. Human Biology, 41(2), 161-175.

Damon, A., \& Bajema, C. J. (1974). Age at menarche: accuracy of recall after thirty-nine years. Human Biology, 46(3), 381-384.

Datta Banik, S., Méndez, N., \& Dickinson, F. (2015). Height growth and percentage of body fat in relation to early menarche in girls from Merida, Yucatan, Mexico. Ecology of Food and Nutrition, 54(6), 644-662.

Deardorff, J., Abrams, B., Ekwaru, J. P., \& Rehkopf, D. H. (2014). Socioeconomic status and age at menarche: an examination of multiple indicators in an ethnically diverse cohort. Annals of Epidemiology, 24(10), 727-733.

Deardorff J., Berry-Millet R., Rehkopf D., Luecke E., Lahiff M., \& Abrams B. (2013). Maternal pre-pregnancy BMI, gestational weight gain, and age at menarche in daughters. Maternal and Child Health Journal, 17(8), 1391-1398.

Denham, M., Schell L. M., Deane, G., Gallo, M. V., Ravenscroft, J., \& DeCaprio, A. P. (2005). Relationship of lead, mercury, mirex, dichlorodiphenyldichloroethylene, hexachlorobenzene, and polychlorinated byphenyls to timing of menarche among Akwesasne Mohawk girls. Pediatrics, 115(2), e127-e134.

Dickinson, F., Castillo, T., Vales, L., \& Uc, L. (1995). Migration, socioeconomic status and age at menarche and age at menopause in the Yucatan, Mexico. International Journal of Anthropology, 10(1), 24-28.

dos Santos Silva, I., De Stavola, B. L., Mann, V., Kuh, D., Hardy, R., \& Wadsworth, M. E. J. (2002). Prenatal factors, childhood growth trajectories and age at menarche. International Journal of Epidemiology, 31(2), 405-412.

Dvornyk, V., \& Haq, W. (2012). Genetics of age at menarche: a systematic review. Human Reproductive Update, 18(2):198-210.

Ellis, B. J., McFadyen-Ketchum, S., Dodge, K. A., Pettit, G. S., \& Bates, J. E. (1999). Quality of early family relationships and individual differences in the timing 
of pubertal maturation in girls: a longitudinal test of an evolutionary model. Journal of Personality and Social Psychology, 77(2), 387-401.

Ellis, B. J., \& Garber, J. (2000). Psychosocial antecedents of variation in girls' pubertal timing: maternal depression, stepfather presence, and marital and family stress. Child Development, 71(2), 485-501.

Ellis, B. J. (2004). Timing of pubertal maturation in girls: an integrated life history approach. Psychological Bulletin, 130(6), 920-958.

Ellison, P. T., \& Reiches, M. W. (2012). Puberty. In N. Cameron, \& B. Bogin (Eds.), Human Growth and Development. Amsterdam: Elsevier.

Ersoy, B., Balkan, C., Gunay, T., \& Egemen, A. (2005). The factors affecting the relation between the menarcheal age of mother and daughter. Child Care Health and Development, 31(3), 303-308.

Gomula, A., \& Koziel, S. (2015). Post-migration adaptation and age at menarche in the second generation of migrants. Anthropologischer Anzeiger, 72(2), 245-255.

Henneberg, M., \& Louw, G. J. (1995). Average menarcheal age of higher socioeconomic status urban Cape Coloured girls assessed by means of status quo and recall methods. American Journal of Physical Anthropology, 96(1), 1-5.

Hermanussen, M., Lehmann, A., \& Scheffler, C. (2012). Psychosocial pressure and menarche: A review of historic evidence for social amenorrhea. Obstetrical \& Gynecological Survey, 67(4), 237-41.

Hill, K. (1993) Life history theory and evolutionary anthropology. Evolutionary Anthropology, 2(3), 78-88.

Hoier, S. (2003). Father absence and age at menarche. A test of four evolutionary models. Human Nature, 14(3), 209-233.

INEGI. (2016). Encuesta Intercensal 2015. Panorama sociodemográfico de Yucatán. México: Instituto Nacional de Estadística y Geografía. Available at 
http://www3.inegi.org.mx/sistemas/Panorama2015/Web/Contenido.aspx\#Yucatán3 1000 consulted on February 2017.

Ibañez, L., Ferrer, A., Marcos, M. V., Hierro, F. R., \& de Zegher, F. (2000). Early puberty: rapid progression and reduced final height in girls with low birth weight. Pediatrics, 106(5), e72.

Juarez, F., Quilodran, J., \& Zavala de Cosio, M. E. (1996). Nuevas pautas reproductivas en México. México: El Colegio de México.

Kanazawa, S. (2001). Why father absence might precipitate early menarche: the role of polygyny. Evolution and Human Behaviour, 22(5), 329-334.

Keim S. A., Branum, A. M., Klebanoff, M. A., \& Zemel B. S. (2009). Maternal body mass index and daughters' age at menarche. Epidemiology, 20(5), 677-681.

Khan, A. W., Schroeder, D. G., Martorell, R., Haas, J. D., \& Rivera, J. (1996). Early childhood determinants of age at menarche in rural Guatemala. American Journal of Human Biology, 8(6), 717-723.

Kim, K., Smith, P. K., \& Palermiti, A. L. (1997). Conflict in childhood and reproductive development. Evolution and Human Behaviour, 18(2), 109-142.

Koprowski, C., Ross, R. K., Mack, W. J., Henderson, B. E., \& Bernstein, L. (1999). Diet, body size, and menarche in a multi-ethnic cohort. British Journal of Cancer, 79(11-12), 1907-1911.

Krzyzanowska, M., Mascie-Taylor, C. N., \& Thalabard, J. C. (2015). Biosocial correlates of age at menarche in a British cohort. Annals of Human Biology, 43(3), 235-240.

Kuzawa, C. W. (2005). Fetal origins of developmental plasticity: Are fetal cues reliable predictors of future nutritional environments? American Journal of Human Biology, 17(1), 5-21.

Levy, S. 2006. Progress against poverty - Sustaining Mexico's 
PROGRESA - Oportunidades Program. Washington DC: Brookings Institution Press.

Livson, N., \& McNeill, D. (1962). The accuracy of recalled age of menarche. Human Biology, 34(3), 218-221.

Lizama Quijano, J. J. (2012). Del pueblo a la urbe. El perfil maya de la blanca Mérida. México: Centro de Investigaciones y de Estudios Superiores en Antropología Social.

Loukid, M., Baali, A., \& Hilali, M. K. (1996). Secular trend in age at menarche in Marrakesh (Morocco). Annals of Human Biology, 23(4), 333-335.

Lovell W. G. (2010). A beauty that hurts: Life and survival in Guatemala. 2nd edition. Austin: University of Texas Press.

Malina, R. M., Ryan, R. C., \& Bonci, C. M. (1994). Age at menarche in athletes and their mothers and sisters. Annals of Human Biology, 21(5), 417-422.

Malina, R. M., Katzmarzyk, P. T., Bonci, C. M., Ryan, R. C., \& Wellens R. E. (1997). Family size and age at menarche in athletes. Medicine and Sciences in Sports and Exercise, 29(1), 99-106.

Malina, R. M., Peña Reyes, M. E., Tan, S. K., \& Little, B. B. (2004). Secular change in age at menarche in rural Oaxaca, southern Mexico: 1968-2000. Annals of Human Biology, 31(6), 634-646.

Méndez, N., The Late Mario Barrera-Pérez., Palma-Solís, M., Zavala-Castro, J., Dickinson, F., Azcorra, H., \& Prelip, M. (2016). Ethnicity and income impact on BMI and stature of school children living in urban southern Mexico. Journal of Biosocial Science, 48(2), 143-157.

Moisan, J., Meyer, F., \& Gingras, S. (1990). A nested case-control study of the correlates of early menarche. American Journal of Epidemiology, 132(5), 953-961. 
Morris, D. H., Jones, M. E., Schoemaker, M. J., Ashworth, A., \& Swerdlow, A. J. (2011). Familial concordance for age at menarche: analyses from the breakthrough generations study. Paediatric and Perinatal Epidemiology, 25(3), 306-311.

Morris, D. H., Jones, M. E., Schoemaker, M. J., Ashworth, A., \& Swerdlow, A. J. (2010). Determinants of age at menarche in the UK: analyses from the Breakthrough Generations Study. British Journal of Cancer, 103(11), 1760-1764.

Must, A., Phillips, S. M., Naumova, E. N., Blum, M., Harris, S., Dawson-Hughes, B., \& Rand, W. M. (2002). Recall of early menstrual history and menarcheal body size: after 30 years, how well do women remember? American Journal of Epidemiology, 155(7), 672-679.

Padez, C. (2003). Age at menarche of schoolgirls in Maputo, Mozambique. Annals of Human Biology, 30(4), 487-495.

Peña Gómez, R. M. (1970). Edad de la menarquía en tres grupos de niñas mexicanas. México: Instituto Nacional de Antropología e Historia.

Perry, J. R. B., Stolk, L., Franceschini, N., Lunneta, K. L., Zhai, G., McArdle, P. F., ... Murabito, J. M. (2009). Meta-analysis of genome-wide association data identifies two loci influencing age at menarche. Nature Genetics, 41(6), 648-650.

Ramírez Carrillo, L. A. (2015). Pobres pero globales. Desarrollo y desigualdad social en el sureste de México. México: Universidad Autónoma de Yucatán Miguel Ángel Porrúa.

Rigon, F., Bianchin, L., Bernasconi, S., Bona, G., Bozzola, M., Buzi, F., ... Perissinotto, E. (2010). Update on age at menarche in Italy: toward the levelling off of the secular trend. Journal of Adolescent Health, 46(3), 238-244.

Siniarska, A., \& Wolanski, N. (1999). Secular changes and economic transformations in Yucatan, Mexico. Perspectives in Human Biology, 4(2), 189201. 
Szwed, A., John, A., Czapla, Z., \& Kosinska, M. (2013). Influence of socioeconomic factors on age at menarche of Polish girls. Anthropologischer Anzeiger, 70(4), 455-470.

Uche, G. O., \& Okorafor, A. E. (1979). The age of menarche in Nigerian urban school girls. Annals of Human Biology, 6(4), 395-398.

Varela-Silva, M. I., Dickinson, F., Wilson, H., Azcorra, H., Griffiths, P. I., \& Bogin, B. (2012). The nutritional dual burden in developing countries - How is it assessed and what are the health implications? Collegium Antropologicum, 36(1), 39-45.

Wells, J. C. K. (2007). The thrifty phenotype as an adaptive maternal effect. Biological Reviews of the Cambridge Philosophical Society, 82(1), 143-172.

Wells, J. C. K. (2010). Maternal capital and the metabolic ghetto: an evolutionary perspective on the transgenerational basis of health inequalities. American Journal of Human Biology, 22(1), 1-17.

Wolanski, N., Dickinson, F., \& Siniarska, A. (1993). Biological traits and living conditions of Maya Indian and non-Maya girls from Merida, Mexico. International Journal of Anthropology, 8(4), 233-246.

Worthman, C. M. (1999). Evolutionary perspectives on the onset of puberty. In W. R. Trevathan, E. O. Smith \& J. J. Mckena (Eds.), Evolutionary Medicine. New York: Oxford University Press.

Yermachenko, A., \& Dvonrnyk, V. (2014). Nongenetic determinants of age at menarche: a systematic review. BioMed Research International, available at https://www.hindawi.com/journals/bmri/2014/371583/.

Zarow, R., \& Chichocka, B. A. (2008). A comparative analysis of estimation of age at menarche by various methods in women participating in the Krakow Longitudinal Study, Poland. American Journal of Human Biology, 20(2), 146-148. 
Table 1 Differences in socioeconomic indicators between mothers and daughters by childhood living conditions variables

\begin{tabular}{|c|c|c|c|c|c|}
\hline \multirow[t]{2}{*}{ Variable } & \multicolumn{2}{|c|}{ Mothers } & \multicolumn{2}{|c|}{ Daughters } & \multirow[t]{2}{*}{$p$-value } \\
\hline & Mean & SD & Mean & SD & \\
\hline Number of siblings & 6.78 & 3.17 & 5.42 & 2.68 & $\begin{aligned} t & =-5.26 \\
& <0.001\end{aligned}$ \\
\hline $\begin{array}{l}\text { Household characteristics } \\
\text { Floor }\end{array}$ & Freq & $\%$ & Freq & $\%$ & \\
\hline $\begin{array}{l}\text { Perishable materials } \\
\text { Durable materials }\end{array}$ & $\begin{array}{r}172 \\
74\end{array}$ & $\begin{array}{l}70 \\
30\end{array}$ & $\begin{array}{r}68 \\
178\end{array}$ & $\begin{array}{l}27 \\
73\end{array}$ & $\begin{array}{c}X^{2}{ }_{(1)}=5.37 \\
0.020\end{array}$ \\
\hline Wall & & & & & \\
\hline $\begin{array}{l}\text { Perishable materials } \\
\text { Durable materials }\end{array}$ & $\begin{array}{r}147 \\
99\end{array}$ & $\begin{array}{l}60 \\
40\end{array}$ & $\begin{array}{r}68 \\
178\end{array}$ & $\begin{array}{l}28 \\
72\end{array}$ & $\begin{array}{l}\mathrm{X}^{2}{ }_{(1)}=12.92 \\
<0.001\end{array}$ \\
\hline Ceiling & & & & & \\
\hline $\begin{array}{l}\text { Perishable materials } \\
\text { Durable materials }\end{array}$ & $\begin{array}{r}221 \\
25\end{array}$ & $\begin{array}{l}90 \\
10\end{array}$ & $\begin{array}{r}147 \\
99\end{array}$ & $\begin{array}{l}60 \\
40\end{array}$ & $\begin{array}{c}\mathrm{X}^{2}{ }_{(1)}=0.70 \\
0.404\end{array}$ \\
\hline $\begin{array}{l}\text { Household conditions inde } \\
\text { Bad } \\
\text { Regular } \\
\text { Good }\end{array}$ & $\begin{array}{r}128 \\
59 \\
59\end{array}$ & $\begin{array}{l}52 \\
24 \\
24\end{array}$ & $\begin{array}{r}43 \\
44 \\
159\end{array}$ & $\begin{array}{l}17 \\
18 \\
65\end{array}$ & $\begin{array}{c}\mathrm{X}^{2}(4)=7.91 \\
0.095\end{array}$ \\
\hline $\begin{array}{l}\text { Comparison of number } \\
\text { daughters were done th } \\
\text { durable materials of hou } \\
\text { daughters using chi-squ }\end{array}$ & $\begin{array}{l}\text { S duri } \\
\text {-test a } \\
\text { were }\end{array}$ & $\begin{array}{l}\text { hild } \\
\text { prop }\end{array}$ & $\begin{array}{l}\text { d bet } \\
\text { ions c }\end{array}$ & $\begin{array}{l}n \text { moth } \\
\text { rishab }\end{array}$ & $\begin{array}{l}\text { rs and } \\
\text { and } \\
\text { and }\end{array}$ \\
\hline
\end{tabular}


Table 2 Mean and standard deviations of daughters' age at menarche according to socioeconomic conditions experienced by mothers and daughters

\begin{tabular}{|c|c|c|c|}
\hline \multirow[t]{2}{*}{ Socioeconomic parameter } & \multicolumn{2}{|c|}{$\begin{array}{l}\text { Daughters' age at } \\
\text { menarche (years) }\end{array}$} & \multirow[t]{2}{*}{$\begin{array}{l}\text { Test and } \\
\text { P-value }\end{array}$} \\
\hline & Mean & & \\
\hline \multicolumn{4}{|c|}{ Maternal household conditions index } \\
\hline $\operatorname{Bad}(n=128)$ & 12.20 & 1.49 & $E=3.0$ \\
\hline Regular $(n=59)$ & 12.12 & 1.54 & $P=0.052$ \\
\hline Good $(n=59)$ & 11.62 & 1.59 & \\
\hline \multicolumn{4}{|l|}{$\begin{array}{l}\text { Daughter Household conditions } \\
\text { index }\end{array}$} \\
\hline $\operatorname{Bad}(n=43)$ & 12.14 & 1.59 & $F=0.76$ \\
\hline Regular $(n=44)$ & 12.26 & 1.57 & $P=0.470$ \\
\hline $\operatorname{Good}(n=159)$ & 11.95 & 1.46 & \\
\hline
\end{tabular}


